\title{
The Response of Different Planes of Nutrition and Analyzing its Effects on Nutrients Dynamics and Growth Rate in Ruminants: A Review
}

\author{
Prince Chauhan $^{1}$, Rajneesh ${ }^{2 *}$, Shambhvi ${ }^{1}$, Narender Kumar ${ }^{3}$ and Shwetambri Jamwal ${ }^{4}$ \\ ${ }^{1}$ Animal Nutrition department NDRI, Karnal, India \\ ${ }^{2}$ Livestock Production Management, IVRI, Bareilly, India \\ ${ }^{3}$ Department of LFC, LUVAS, Hisar, India \\ ${ }^{4}$ Livestock Production Management, GBPUAT, Pantnagar, India
}

*Corresponding author

\section{A B S T R A C T}

\section{Keywords \\ Energy, Nutrients, Protein, Ruminants \\ Article Info \\ Accepted: \\ 12 December 2020 \\ Available Online: \\ 10 January 2021}

With advances in animal nutrition, there is more concern towards fulfillment of nutrient requirements for maintenance and production level of ruminants. Among nutrients, energy and protein are the most important nutrients in the ration as both energy and proteins have a direct role in the functioning of all other physiological, biochemical, and other nutrients metabolism. To evaluate the role of various concentrations of energy and protein parameters like dry matter intake (DMI), digestibility, Nitrogen dynamics, and body weight changes must be studied thoroughly. Therefore, this review sums up the impact of different levels of energy and protein on nutrient digestibility, nutrient balance, DMI and on growth rates.

\section{Introduction}

With largest sharing of livestock population, animal nutrition is an integral part in tropical countries like India and as far as nutrient utilization is considered, role of energy and protein is very direct to animal longevity and productivity. Growing period is one of the most essential phases in ruminants and has considerable impacts throughout life, however nutritional management of calves is not given its due importance and animals are fed with poor quality feed and fodder during this period. Energy and protein play a critical role in influencing animals to reach their productive age and body weight. Under as well as imbalance nutrition causes significant effects on nutritional status of other nutrients also. Balancing the supply of nitrogen and energy to rumen microbes by judicial use of nutrients is the demand of the hour in animal nutrition studies. In tropics as feed and fodder available are mostly of poor quality and poorly utilized thus decreases nutrient availability to animals. Hence to evaluate adequate nutritional status through measurement of various parameters becomes very important. Genetics, environment, 
balanced nutrition, hormones and enzymes control the growth of the animal. Growth rate also functions as important character to determine the lifetime production of an animal (Lawrence and Fowler, 1997). Bodyweight as a parameter is important as maturity and productivity of animals is more correlated with bodyweight than the age. To increase growth rate and feed conversion efficiency (FCE), energy level plays a significant role (Anjum et al., 2012). DMI also affects microbial growth in rumen. From a livestock farmer's point of view, they need more digestible feed to keep their animals in good health and in good production. Over the past few years, animal nutrition studies based on supplying different levels of energy and proteins have been developed and applied with varying degree of success. Thus in this review we are summarizing effects of various concentrations of energy and protein during growth periods in ruminants on nutrient digestibility and growth rate.

\section{Effect of different levels of dietary energy and protein on nutrient digestibility}

A study was conducted at LUVAS-Hisar, on heifers of 13 to 14 months of age with $153 \pm$ $6.41 \mathrm{~kg}$ average body weight by Jakhar et al., (2014) to evaluate the response of different protein sources (MOC, GNC, CSC and SBM). The rations were made iso-caloric $(74 \%)$ and iso-nitrogenous $(20 \% \mathrm{CP})$. The digestibility of nutrients (DM, OM, CP, EE, CF, and NFE) was observed during the experiment, but the results showed no significant difference by feeding different sources of protein.

Mustafa et al., (2017) evaluate different levels of $\mathrm{ME}$ and MP in 15 transition Murrah buffaloes. The trial was conducted for 160 days i.e. 40 days before parturition and 120 days after parturition. Control group was fed as ICAR (2013) recommendations. First treatment group (HMEMP) was fed with $15 \%$ higher ME and MP and second treatment group (LMEMP) was fed with $15 \%$ lower ME and MP levels. Apparent digestibility coefficient (Mean \pm SE) of control group for DM, OM, CP, EE, NDF and ADF were 68.0 $\pm 0.91,69.3 \pm 0.30,66.5 \pm 0.85,79.3 \pm 0.67$ $62.1 \pm 1.15$ and $48.9 \pm 1.31$ respectively whereas apparent digestibility coefficient (Mean \pm SE) of HMEMP for DM, OM, CP, $\mathrm{EE}, \mathrm{NDF}$ and ADF were $68.2 \pm 0.88,69.5 \pm$ $0.30,67.2 \pm 0.82,79.6 \pm 0.65,62.3 \pm 1.11$ and $49.2 \pm 1.27$ respectively and apparent digestibility coefficient (Mean \pm SE) of LMEMP for DM, OM, CP, EE, NDF and ADF were $67.9 \pm 0.84,68.6 \pm 0.30,65.7 \pm$ $0.78,78.8 \pm 0.62,61.8 \pm 1.06$ and $48.8 \pm 1.21$ respectively. Therefore results of nutrient digestibility showed no significant difference among the three groups. Umunna et al., (1980) made three rations which were isocaloric with three different CP levels $11.6 \%$, $14.7 \%$ and $17.7 \%$ (low, medium and high). Rations made in this study were fed to thirty fattening steers (Zebu) by dividing animals equally into three treatments $(n=10)$. Results observed for dry matter digestibility (\%) of low and medium CP level were equal $(70.0 \%)$ but for high protein level it was $66.7 \%$ however value did not decreased significantly. Protein digestibility increases with increasing in $\mathrm{CP}$ levels but did not change significantly. Results for protein digestibility (\%) of low, medium and high levels of CP treatment group were 74.0, $75.2 \%$ and $77.5 \%$ respectively.

A study was conducted at IGFRI-Jhansi. U.P. by Singh et al., (2009) to evaluated nutrient efficiency and $\mathrm{N}$ balance in fifteen Bhadawari buffalo calves by dividing 5 animals in three groups (G1, G2 and G3). In G1 animals were fed with $\mathrm{CP}$ and $\mathrm{ME}$ accordance to NRC (2001), G2 was fed with 20\% lower CP than G1 and in G3 animals were fed with $20 \%$ higher $\mathrm{CP}$ than $\mathrm{G} 1$. CP digestibility (\%) in $\mathrm{G} 1, \mathrm{G} 2$ and $\mathrm{G} 3$ were $57.93 \pm 2.59,47.10 \pm$ 
2.84 and $63.72 \pm 2.13$ hence treatment with $20 \%$ less CP level (G2) showed significantly lesser digestibility than G1 and G2 and DM digestibility (\%) was significantly higher $(62.33 \pm 1.68)$ in $\mathrm{G} 3$ when compared to $\mathrm{G} 2$ (55.84 \pm 1.64). Higher cell wall contents could be the cause of lower DM and $\mathrm{CP}$ digestibility. NDF, ADF and Cellulose digestibility (\%) was not found to be altered significantly however G3 group showed significantly lower hemicellulose digestibility than other groups. Shahzad et al., (2011) analyzed the effect of different levels of energy and protein on 12-15 month Nili-Ravi calves (average body weight $=140 \pm 14 \mathrm{~kg}$ ) by making twelve rations based on four different levels of CP $(10.50 \%, 12.50 \%$, $13.80 \%$ and $15.55 \%$ ) with three different levels of $\mathrm{ME}(1.72 \%, 2.11 \%$ and $2.5 \mathrm{Mcal} / \mathrm{kg})$ and fed to different groups with five calves in each group ( $4 \times 3$ factorial design) for 100 days. Crude protein digestibility was not altered significantly due to effect of different levels of protein and different levels of energy. NDF digestibility was highest $(p<0.05)$ in high protein level group $(53.98 \%)$ than other levels of proteins, however, DM digestibility does not differ among different levels of protein. Results of the study for DM digestibility for different levels of energy (low, medium and high) were 55.88, 58.25 and 64.50 which was statistically significant $(p<0.05)$ in all treatments group. For different energy levels, the observed NDF digestibility for low, medium and high levels of protein were $50.47 \%, 52.70 \%$ and $54.24 \%$ respectively.

Another study conducted at NDRI-karnal to analyze the effect of different levels of energy and protein on nutrient utilization by Prusty $e t$ al., (2016) for 150 days on 30 Murrah buffalo calves. For the study six treatment groups were made based on six ration prepared with 90, 100 and $110 \%$ CP level and 90 and 110\% ME levels of requirements of buffalo calves
(ICAR 2013). The result of this study showed a significant difference in nutrients digestibility. DM digestibility coefficient (\%) varied from $51.0 \pm 1.36$ (low ME-High $\mathrm{CP}$ ) to $63.4 \pm 1.02$ (high ME- high CP). CP digestibility coefficient (\%) increases with increasing in $\mathrm{CP}$ levels with low $\mathrm{ME}$ and similar increasing trend was observed with high ME. EE digestibility of low CP, medium $\mathrm{CP}$ and high $\mathrm{CP}$ with low ME were $78.1 \pm$ $0.94,58.8 \pm 1.30$ and $57.7 \pm 2.79$ respectively whereas EE digestibility of low $\mathrm{CP}$, medium $\mathrm{CP}$ and high $\mathrm{CP}$ with high ME were $75.2 \pm$ $2.19, \quad 72.7 \pm 1.18$ and $68.5 \pm 1.30$ respectively. Tauqir et al., (2011) conducted a study on growing male buffalo calves for different protein and energy concentrations to evaluate nutrient utilization and weight gain. Three levels of CP (11.85, 14.22 and 16.50\%) and two level of ME (1.86 and $2.23 \mathrm{Mcal} / \mathrm{kg}$ ) were fed to thirty six calves of similar age (180 \pm 10 days). For different levels of protein $\mathrm{CP}$ digestibility (\%), there is no significant difference among the various levels of protein however DM digestibility (\%) alters significantly among low, medium and high protein levels and values were $63.96 \%, 64.01 \%$ and $64.16 \%$ respectively. NDF digestibility for different levels of protein was significantly higher in the high protein group $(55.09 \%)$ when compared to the medium (53.47\%) and low protein group $(53.16 \%)$. For different levels of energy, CP digestibility was found to be non significant different whereas DM and NDF digestibility (\%) varied significantly among two levels of ME. DM digestibility for low and high energy levels were $63.95 \%$ and $64.14 \%$ respectively and NDF digestibility for low and high energy levels were $53.19 \%$ and $54.63 \%$ respectively.

A study conducted by Singh et al., (2015) at IGFRI-Jhansi, U.P. to analyzed the response of dietary protein levels on nutrient utilization and nitrogen balance. For conducting study 15 Bhadawari buffalo heifers were divided into 
three groups $(n=5)$ in which similar energy but three different levels of protein of rations were fed. Three different groups in the study were SPG had protein as per requirement, LPG had $20 \%$ less protein than the standard group and HPG had $20 \%$ more protein than SPG. Results from the study showed no significant difference in DM, OM, NDF and ADF digestibility among LPG, SPG and HPG however $\mathrm{CP}$, EE, Cellulose and hemicellulose digestibility among different groups were significant. CP digestibility (\%) was lower (p\&lt;0.05) in LPG (61.47\%) when compared to SPG $(66.15 \%)$ and HPG (69.94\%). EE digestibility (\%) for LPG, SPG and HPG were $75.38 \%, 72.93 \%$ and $84.13 \%$ respectively therefore values was significant among different groups. Cellulose digestibility was significant between LPG (54.66\%) and HPG (61.43) however values were comparable to SPG (56.05\%). Digestibility coefficient for hemi-cellulose was lowest in LPG (58.98\%) and significant to SPG $(67.06 \%)$ and comparable to $\mathrm{HPG}$ $(64.84 \%)$.

\section{Effect of different levels of dietary energy and protein on dry matter intake}

To analyze the effect of different levels of energy and protein and their combination on nutrient digestibility was studied by Shahzad et al., (2011) on 12-15 month Nili-Ravi calves (average body weight $=140 \pm 14 \mathrm{~kg}$ ). In this study, 12 rations were made on four different levels of CP $(10.5 \%, 12.50 \%, 13.80 \%$ and $15.55 \%$ ) with three different levels of $\mathrm{ME}$ $(1.72 \%, 2.11 \%$ and $2.5 \mathrm{Mcal} / \mathrm{kg})$ and fed to 60 animals equally divided into 12 groups for 100 days. Results of the study showed statistically significant $(p<0.05 \%)$ daily feed consumption in all treatments group. For different CP levels, the observed DMI $(\% \mathrm{BW})$ were $2.45 \%, 2.75 \%, 2.37 \%$ and $2.22 \%$ and for different levels of ME, observed DMI (\%BW) were $2.75 \%, 2.63 \%$ and $1.96 \%$. Girdhar et al., (2008) evaluated three different energy levels of the ration and NRC (1989) (group 1 as Military farm feeding schedule, group 2 as per NRC and group 3 as $20 \%$ higher energy level than NRC) on adult Frieswal bulls. In this study, DMI was found significantly higher $2.02 \mathrm{~kg}$ (group 3) when compared to $2.01 \mathrm{~kg}$ (group1).

Umunna et al., (1980) made three rations which were iso-caloric with three different $\mathrm{CP}$ levels $(11.6 \%, 14.7 \% 17.7 \%)$ and fed to steers. In this study, it was observed that DMI was increased from low $(11.6 \%)$ to medium (14.7\%) level of CP with values 6.11 to 6.63 $\mathrm{kg}$ /day but decreased when $\mathrm{CP}$ level was further increased to high $(17.7 \%)$ level, the DMI decreased to $6.23 \%$. Prusty et al., (2016) conducted a study of 150 days on Murrah buffaloes calves at NDRI-karnal to optimize and analyze the effect of different levels of energy and protein on growth and nutrient utilization. The experiment was conducted on 30 calves $(202.5 \pm 6.8 \mathrm{~kg})$ which were divided into six treatment groups based on six rations prepared with 90, 100 and $110 \% \mathrm{CP}$ level and 90 and $110 \%$ ME levels of requirements of buffalo calves (ICAR 2013). Results of this study showed no significant difference in average DMI and DMI (\%BW). Average DMI ranged from $5.25 \mathrm{~kg}$ in low ME-low CP group to $5.86 \mathrm{~kg}$ in the high ME- high $\mathrm{CP}$ group similarly DMI $(\mathrm{kg}, 100 \mathrm{~kg} \mathrm{BW})$ varied from $2.21 \%$ to $2.39 \%$ in low ME-low CP and high ME-high CP group respectively.

A study was conducted at LUVAS-Hisar, Haryana by Jakhar et al., (2014) to evaluate the response of different protein sources (MOC, GNC, CSC and SBM) fed to twenty Murrah buffalo heifers divided equally into 4 groups with different protein sources. To eliminate the effect of levels of $\mathrm{CP}$ and $\mathrm{ME}$, the rations were made iso-caloric $(74 \%)$ and iso-nitrogenous $(20 \% \mathrm{CP})$. Heifers used in the study were of 13 to 14 months of age with 
$153 \pm 6.41 \mathrm{~kg}$ average body weight. Observed results for DMI $(\mathrm{kg} / \mathrm{d})$, DMI $(\% \mathrm{BW})$ and DMI (g, metabolic body weight) showed no significant difference among treatments. DMI $(\mathrm{kg} / \mathrm{d})$ values varied from $5.74 \pm 0.15$ (MOC) to $6.08 \pm 0.26$ (CSC) and $\mathrm{DMI}(\% \mathrm{BW})$ observed values for MOC, GNC, CSC and SBM were $2.51 \pm 0.19,2.52 \pm 0.14 \%, 2.57 \pm$ 0.10 and $2.40 \pm 0.04$ respectively. The lowest value for DMI (g, metabolic weight) was $94.61 \pm 3.64$ for SBM treated group whereas the highest observed value for DMI (g, metabolic weight) was $100.86 \pm 3.67$ for CSC treated group. Davidson and his co-workers in 2003 evaluated nutrient utilization and dry matter intake by feeding different $\mathrm{CP}$ levels $(16.5 \%, 16.8 \%, 17.2 \%$ and $19.2 \%)$ in TMR to 65 Holstein cows and observed DMI (kg, day) were 24.1, 23.4, 23.1, 22.9 and 23.3 respectively. Brown et al., (2005) analyzed DMI and body growth on heifer calves by feeding increasing levels of protein. Results of this study showed no significant difference in DMI (kg/day). Tauqir et al., (2011) conducted a study on growing male buffalo calves for different protein and energy concentrations to evaluate nutrient utilization and weight gain. Three level of CP (11.85, 14.22 and $16.50 \%$ ) and two-level of $\mathrm{ME}$ ( $1.86 \%$ and $2.23 \mathrm{Mcal}, \mathrm{kg}$ ) were fed to thirtysix calves of similar age $(180 \pm 10$ days $)$. DMI was observed equal $(2.34 \mathrm{~kg})$ when two level of energy were fed in different treatment group however DMI had not changed significantly when CP was fed at a level of $11.85 \%$ (low) and $14.25 \%$ (medium) but DMI decreased (p\&lt;0.05) when $16.5 \%$ level of CP was fed.

An experiment was conducted on 15 months buffalo male calves (B.wt.287 $\pm 15 \mathrm{~kg}$ ) fed with three levels of energy, and three levels of proteins by Mahmoudzadeh et al., (2007) to evaluate various growth parameters. Results observed during the study showed significant differences $(p<0.05)$ among treatments of the interaction of energy and protein levels for DMI (kg/day), DMI (\% of BW) and in DMI ( $\mathrm{g} / \mathrm{kg}$ metabolic BW). The values for DMI (\%BW) ranged from $1.50 \%$ to $2.05 \%$. Kumar et al., (2015) selected 18 Murrah bulls from the Artificial Breeding Research Centre of NDRI, Karnal, Haryana. The selected animals were of average age 24 months and body weight $428 \mathrm{~kg}$ and divided into three groups $(n=6)$. Animals of group 1 (G1, control) were fed by the ICAR (2013) recommendations; group 2 (G2) were fed with $10 \%$ higher energy and group 3 (G3) were fed with $20 \%$ higher energy than ICAR (2013) recommendations. DMI (\%BW) observed results showed a significant increase in G3 $(2.29 \% \pm 0.20)$ when compared to $\mathrm{G} 2(2.23 \pm$ $0.02)$ and G1 $(2.16 \% \pm 0.02)$. Mustafa et al., (2017) evaluate the different levels of ME and MP in transition Murrah buffaloes with an expected producing ability (EPA) of 2125.7 \pm 46.34. Fifteen animals were divided equally $(n=5)$ into three groups. The trial was conducted for 160 days i.e. 40 days before parturition and 120 days after parturition. The Control group was fed as ICAR (2013) recommendations; the first treatment group (HMEMP) was fed with $15 \%$ higher ME and MP and the second treatment group (LMEMP) was fed with $15 \%$ lower ME and MP levels. DMI (\%BW) of control, HMEMP and LMEMP were $2.7 \pm 0.11,2.8 \pm 0.11$ and $2.6 \pm 0.12$ respectively which showed no significant alteration. Jamara et al., (2015) analyzed the effect on puberty and weight gain by feeding Shatavari $(150 \mathrm{mg} / \mathrm{kg}$ BW/day) to Sahiwal heifers. DMI $(\mathrm{kg} / \mathrm{d})$ in the control was $4.70 \pm 0.09$ and the supplemented group was $5.35 \pm 0.18$, showed higher DMI in the treatment group $(\mathrm{p}<0.05)$. Another study was conducted to evaluate the effect of photoperiod on DMI, and puberty by Kassim et al., (2008) on buffalo heifers. They reported no alteration in DMI by long photoperiod and natural photoperiod cycle. 
Table.1 Effect of different levels of dietary energy and protein on nitrogen balance

\begin{tabular}{|c|c|c|c|}
\hline S.No. & Plan of study & Nitrogen utilization & $\begin{array}{l}\text { Place of study and } \\
\text { References }\end{array}$ \\
\hline 1. & $\begin{array}{l}\text { Evaluation of three levels of dietary } \\
\text { protein in Bhadawari buffalo calves } \\
\text { Three treatment group made were } \\
\text { G1: CP level in accordance to NRC } \\
\text { (2001) } \\
\text { G2: } 20 \% \text { less CP than G1 } \\
\text { G3: } 20 \% \text { more CP than G1 }\end{array}$ & $\begin{array}{l}\mathrm{N} \text { intake }(\mathrm{g} / \mathrm{d}) \text { in } \mathrm{G} 1, \mathrm{G} 2 \text { and } \mathrm{G} 3 \text { were } 59.98 \pm \\
4.26,51.26 \pm 3.75 \text { and } 69.56 \pm 3.91 \text { respectively. } \\
\text { Urinary } \mathrm{N} \text { and } \mathrm{N} \text { balance was lower }(\mathrm{p}<0.05) \text { in } \\
\mathrm{G} 2 . \text { Urinary } \mathrm{N}(\mathrm{g} / \mathrm{d}) \text { in } \mathrm{G} 1, \mathrm{G} 2 \text { and } \mathrm{G} 3 \text { were } 8.99 \\
\pm 0.98,5.33 \pm 0.37 \text { and } 10.81 \pm 0.63 \\
\text { respectively. } \mathrm{N} \text { balance }(\mathrm{g} / \mathrm{d}) \text { in } \mathrm{G} 1, \mathrm{G} 2 \text { and } \mathrm{G} 3 \\
\text { were } 22.70 \pm 5.67,17.57 \pm 2.24 \text { and } 33.63 \pm 3.79 \\
\text { respectively. }\end{array}$ & $\begin{array}{l}\text { IGFRI-Jhansi, U.P } \\
\text { Singhet al. (2009) }\end{array}$ \\
\hline 2. & $\begin{array}{l}\text { Six diets formulated on basis of } 90 \% \text {, } \\
100 \% \text { and } 110 \% \text { of protein level with } \\
90 \text { and } 110 \% \text { energy level in } \\
\text { accordance to ICAR (2013) to } 30 \\
\text { Murrah male calves }\end{array}$ & $\begin{array}{l}\text { No significant effect on } \mathrm{N} \text { intake by increasing } \\
\text { energy levels however significantly increases } \\
\text { with increase in protein level. Faecal } \mathrm{N} \text { and } \\
\text { retained } \mathrm{N} \text { showed no significant alteration } \\
\text { among different level of protein and energy. } \\
\text { Absorbed } \mathrm{N} \text { results showed increased ( } \mathrm{p}<0.05 \text { ) } \\
\text { with increase in protein level but difference is not } \\
\text { significant with increase in energy levels. } \\
\text { Absorbed } \mathrm{N} \text { (g) values for low } \mathrm{CP} \text {, medium CP } \\
\text { and high CP (with low ME) were } 98.3 \pm 6.25 \text {, } \\
106.8 \pm 8.60,116.4 \pm 6.95 \text { respectively. } \\
\text { Absorbed } \mathrm{N} \text { (g) values for low CP, medium CP } \\
\text { and high CP (with high ME) were } 96.5 \pm 3.51 \text {, } \\
117.2 \pm 4.39,129.4 \pm 12.31 \text { respectively. }\end{array}$ & $\begin{array}{c}\text { NDRI- karnal, } \\
\text { Haryana } \\
\text { Prusty et al. }(2016)\end{array}$ \\
\hline 3. & $\begin{array}{l}\text { Evaluated different levels of energy } \\
\text { and protein concentrations in rations } \\
\text { of } 36 \text { Nili Ravi calves. Six groups } \\
\text { having } 6 \text { animals in each group with } \\
\text { six different rations one for each } \\
\text { group. Six rations were formulated } \\
\text { on the basis of } 3 \text { levels of CP } \\
(11.85 \%, 14.20 \%, 16.50 \%) \text { each with } \\
2 \text { levels of ME }(1.86 \text { and } 2.23 \\
\text { Mcal/kg). }\end{array}$ & $\begin{array}{l}\text { Nitrogen dynamics parameters were not altered } \\
\text { significantly on various levels of ME whereas } \mathrm{N} \\
\text { intake, faecal } \mathrm{N} \text {, Urinary } \mathrm{N} \text { and } \mathrm{N} \text { balance } \\
\text { showed significant differences when fed with } \\
\text { different levels of } \mathrm{CP} \text { (low, medium and high). } \\
\mathrm{N} \text { intake (g/d) values ranged from } 44.50 \text { (low) to } \\
61.47 \text { (high) for different levels of dietary } \\
\text { proteins and Faecal } \mathrm{N} \text { in low, medium and high } \\
\text { groups were } 13.03,15.56 \text { and } 17.55 \text { respectively. } \\
\text { Lowest level of Urinary } \mathrm{N} \text { (g/d) was found in } \\
\text { low group (24.14) and highest was found in High } \\
\text { protein group (32.51). Urinary } \mathrm{N} \text { increase was } \\
\text { linked with increased ammonia absorbed from } \\
\text { ruminal wall or intestine. } \mathrm{N} \text { balance value for } \\
\text { low, medium and high CP levels group were } \\
7.32,9.17 \text { and } 11.4 \text { respectively. }\end{array}$ & $\begin{array}{l}\text { Pakistan Tauqir et al. } \\
\qquad(2011)\end{array}$ \\
\hline 4. & $\begin{array}{l}\text { Response of various levels of protein } \\
\text { in } 15 \text { Bhadawari buffalo heifers to } \\
\text { nutrient utilization. Animals were fed } \\
\text { with similar energy level i.e. } 2.7 \\
\text { Mcal/kg with different protein levels } \\
: \\
\text { SPG: CP in accordance with ICAR } \\
\text { (1985) } \\
\text { LPG: } 20 \% \text { less CP than SPG } \\
\text { HPG: } 20 \% \text { high CP than SPG }\end{array}$ & $\begin{array}{l}\mathrm{N} \text { intake and faecal } \mathrm{N} \text { values were comparable } \\
\text { among the three groups however } \mathrm{N} \text { retention } \\
(\mathrm{g} / \mathrm{d}) \text { showed significant difference among the } \\
\mathrm{LPG} \text { SPG and HPG and values were } 67.56 \text {, } \\
58.56 \text { and } 79.20 \text { respectively. Urinary } \mathrm{N}(\mathrm{g} / \mathrm{d}) \\
\text { was higher }(\mathrm{p}<0.05) \text { in HPG ( } 74.83) \text { when } \\
\text { compared to SPG }(50.03) \text { and LPG }(47.88) . \mathrm{N} \\
\text { absorbed }(\mathrm{g} / \mathrm{day}) \text { was significantly lower in HPG } \\
(4.37) \text { compared to SPG (17.54) and LPG } \\
(10.69) \text {. }\end{array}$ & $\begin{array}{l}\text { IGFRI-Jhansi, U.P } \\
\text { Singhet al. (2009) }\end{array}$ \\
\hline
\end{tabular}


Effect of different levels of dietary energy and protein on body weight change and growth rate of calves

Seidel et al., (1980) conducted a study on Angus bulls fed with high (133\%) and low $(95 \%)$ energy in the dietary ration of 7-11 month of age; results revealed higher (p\&lt;0.05) gain in body weight on high energy diets than low. To analyze the response of various energy dietary level i.e. low (14 Mcal/bull/day), medium (18 Mcal/bull/day) and high energy content (23 Mcal/bull/day) from 212 to $422 \mathrm{~d}$ of age and pastured for $38 \mathrm{~d}$ were studied on body weight gain and on puberty in bulls. Results observed higher body weight gain in a high energy group than another group of bulls (Pruitt et al., 1986). Girdhar et al., (2008) evaluated three different energy levels of ration and NRC (1989) (group 1 as Military farm feeding schedule, group 2 as per NRC and group 3 as $20 \%$ higher energy level than NRC) on adult Frieswal bulls. In this study, body weight gain was found to be significantly higher in the high energy fed group than compared to low energy fed group. Patil (2013) studied in Murrah buffalo calves (11-12 months) to analyze response of different dietary energy levels. The Control group was fed by NRC (2001), group 2 was fed with $10 \%$ higher energy than control and group 3 was fed with 20\% higher energy level than control. There was no alteration in body weight in male buffaloes when compared between different groups.

Prusty et al., (2016) evaluated body weight, ADG and nutrient intake on Murrah buffalo calves (16 months old) in a study to analyze response of different energy and protein levels at NDRI-Karnal. ADG for high energy group (110\% ME of ICAR-2013) with all three levels of protein $(90,100$ and $110 \% \mathrm{CP}$ of ICAR-2013) were $612 \pm 15.5,641 \pm 13.9$ and $664 \pm 14.3$ which was significantly higher to low energy group (90\% ME of ICAR2013) with all three levels of protein. Shahzad et al., (2011) conducted a study in 12-15 months Nili-Ravi calves (Average body weight $=140 \pm 14 \mathrm{~kg}$ ). In this study, 12 rations were made on four different levels of CP $(10.5 \%, 12.50 \%, 13.80 \%$ and $15.55 \%)$ with three different levels of ME $(1.72 \%$, $2.11 \%$ and $2.5 \mathrm{Mcal} / \mathrm{kg}$ ) and fed to 60 animals equally divided into 12 groups for 100 days. Results of the study showed no alteration in daily weight gain in all treatments group. For different CP levels, the observed daily weight gains $(\mathrm{kg} / \mathrm{d})$ were $0.35,0.45,0.46$ and 0.41 and for different levels of ME, observed daily $(\mathrm{kg} / \mathrm{d})$ were $0.43,0.47$ and 0.35 .

Tauqir et al., (2011) conducted a study on growing male buffalo calves for different protein and energy concentrations to evaluate nutrient utilization and weight gain. Six treatment diets on the basis of three levels of CP $(11.85,14.22$ and $16.50 \%)$ and two level of ME $(1.86 \%$ and $2.23 \mathrm{Mcal} / \mathrm{kg})$ were fed to thirty-six calves of similar age $(180 \pm 10$ days). Animals were fed ad libitum for 100 days and ADG was recorded. ADG was observed in different treatment rations were 390, 400, 370, 470, 390 and 320 grams however ADG had not changed significantly.

A study was conducted at LUVAS-Hisar, Haryana by Jakhar et al., (2014) to evaluate the response of different protein sources (MOC, GNC, CSC and SBM) fed to twenty Murrah buffalo heifers divided equally into 4 groups with different protein sources. Heifers used in study were of 13 to 14 months of age with $153 \pm 6.41 \mathrm{~kg}$ average body weight fed with iso-nitrogenous and iso-caloric concentrates irrespective of type of protein sources. Observed results of MOC, GNC, CSC and SBM for body weight gain/day $(\mathrm{kg})$ were $0.686 \pm 0.059,0.690 \pm 0.047,0.688 \pm$ 0.028 and $0.720 \pm 0.062$ respectively however results did not differ significantly. 
Mahmoudzadeh et al., (2007) to evaluate various growth parameters in an experiment conducted on 15 months buffalo male calves (B.wt.287 $\pm 15 \mathrm{~kg}$ ) fed with three levels of energy and three levels of proteins by. For different diets, final body weight showed no difference among treatments of interaction between energy and protein but results of ADG/animal varied significantly from 503 (high energy with low protein diet) to 951 grams (medium energy with low protein diet). Kumar et al., (2015) selected 18 Murrah bulls of average age 24 months and body weight $428 \mathrm{~kg}$ and divided into three groups $(\mathrm{n}=6)$. Animals of group 1 (G1, control) were fed by the ICAR (2013) recommendations; group 2 (G2) were fed with $10 \%$ higher energy and group 3 (G3) were fed with 20\% higher energy than ICAR (2013) recommendations. ADG $(\mathrm{g} / \mathrm{d})$ of $\mathrm{G} 1, \mathrm{G} 2$ and $\mathrm{G} 3$ were $377.08 \pm$ $3.06,379.34 \pm 3.8$ and $417.79 \pm 3.74$ which did not alter significantly. A study was conducted to evaluate the effect of feeding Shatavari on the body weight of Sahiwal heifers. Sixteen animals were divided into control and treatment groups $(n=8)$ and both groups were fed in accordance to NRC (1989) however treatment group animals were supplemented with Shatavari (150 $\mathrm{mg} / \mathrm{kgBW} /$ day). Growth rate $(\mathrm{g} / \mathrm{d})$ was found to be higher (p\&lt;0.01) in treatment group compared to control group. Umunna et al., (1980) made three rations which were isocaloric with three different CP levels $(11.6 \%$, $14.7 \% 17.7 \%$ ) and fed them to steers. In this study, adjusted daily gain ( $\mathrm{kg} 3)$ of low, medium and high protein levels were 0.56 , 0.60 and 0.73 and it did not differ significantly by various level of proteins in the diet. Yazdani (2005) conducted an experiment in Iran to evaluate the effect of cottonseed meal (CSM) and soya bean meal (SBM) in male buffalo calves. Average body weight was higher (p\&lt;0.05) in SBM however feed conversion efficiency of CSM was significant compare to SBM groups.
Singh et al., (2009) evaluated nutrient efficiency and growth in fifteen Bhadawari buffalo calves by dividing 5 animals in three groups (G1, G2 and G3). In G1 animals were fed with $\mathrm{CP}$ and $\mathrm{ME}$ in accordance to NRC (2001), G2 was fed with 20\% lower CP than G1 and in G3 animals were fed with $20 \%$ higher $\mathrm{CP}$ than $\mathrm{G} 1$. Growth rates $(\mathrm{g} / \mathrm{d})$ in $\mathrm{G} 1$, G2 and G3 were 430.32 \pm 31.94, $407.64 \pm$ 9.82 and $417.30 \pm 33.85$ respectively. Observed results for FCR and Growth rate (g/d) showed no significant difference among the three groups.

Another study was conducted by Sehgal et al., (2016) at NDRI, Karnal-Haryana on 12 male Murrah buffalo calves of average 10 months of age to evaluate the effect of fermented yeast culture (FYC) supplementation on growth and pubertal age. Overall average for body weight gain and ADG in both growing and pre-pubertal period was significantly higher in the supplemented group. Anjum et al., (2012) evaluated stair step nutritional regimen (SSNR) for three energy levels compared to control with fed NRC (2001) recommendations in Nili-ravi heifers. Daily weight gain $(\mathrm{kg})$ in SSNR and control group were $0.63 \pm 0.02$ and $0.59 \pm 0.03$ whereas FCR were 8.78 and 9.36 respectively however both daily weight gain and FCR did not alter significantly among the groups.

In conclusion the different approaches to varying the plane of nutrition were summarized, and it was concluded that optimum levels of energy and proteins are the key factor in growth and nutrient utilization. Growth period nutritional management affects physiological and production levels of animals and its negligence can cause irreversible damage. As we have studied from the above review adequate energy and protein concentration in diet of growing animals is of paramount importance and aids in maintaining DMI and nutrient digestibility 
thus causing a better growth rate. Therefore, feeding growing calves in accordance with their energy and protein requirement (considering wear-tear and its rapid growth) is the path to increase profitability and longevity of ruminants.

\section{References}

Anjum, M. I., Azim, A., Jabbar, M. A., Anwar, M., \& Mirza, I. H. 2012. Age and weight at puberty in Nili-Ravi buffalo heifers reared on three dietary energy restriction periods followed by compensatory growth. Pak. Vet. J. 32(3):367-371.

Brown, E.G., VandeHaar, M.J., Daniels, K.M., Liesman, J.S., Chapin, L.T., Keisler, D.H., Weber Nielsen, M.S. 2005. Effect of increasing energy and protein intake on body growth and carcass composition of Heifer calves. J. Dairy Sci. 88, 585-594.

Davidson, S., Hopkins, B.A., Diaz, D.E., Bolt, S.M., Brownie, C., Fellner, V., Whitlow, L.W., 2003. Effects of amounts and degradability of dietary protein on lactation, nitrogen utilization and excretion in early lactation Holstein cows. J. Dairy Sci. 86:1681-1689.

Girdhar, N., Prasad, R., Kumar, M. and Singh, K. 2008.Effect of different planes of nutrition and mineral supplementation on nutrient utilization and semen quality of Frieswal bulls. Indian J. Anim. Sci. 78(7):764-768.

Jakhar, A., S. S. Grewal, and M. Chaudhari. 2014. Effect of Inclusion of Different Protein Sources in the Diet on Nutrient Utilisation and Growth Performance of Murrah Buffalo Heifers.Indian Journal of Animal Nutrition. 31(3):218-222.

Jamara, M. S., Mehla, R. K., Singh, M., Ali, M. M., \& Chouhan, N. 2014. Effect of the feed Shatavari (Asparagus racemosus) on body weight and puberty of Sahiwal heifers. Int. J. Agric. Sci. Vet. Med, 2(1):64-67.

Kassim, N. S., Afify, A. A., \& Hassan, H. Z. 2008. Effect of photoperiod length on some reproductive traits and hormonal profiles in buffalo heifers. Am. Euras. J. Agric. Environ. Sci. 3(4):646-655.

Kumar, A., Singh, P., Nitharwal, K., Bhakat, M., \& Singh, S. 2015. Effect of Dietary Energy Levels on Growth, Testicular Development and Sperm Production in Murrah Buffalo Young Bulls. Indian Journal of Animal Nutrition. 32(2):160-163.

Lawrence, T.L.J. \& Fowler, V.R. 1997. Growth and puberty in breeding animals. In: Growth of Farm Animals. CAB International, Wallingford, UK, pp. 251.

Mahmoudzadeh, H., Fazaeli, H., Kordnejad, I., \& Mirzaei, H. R. 2007. Response of male buffalo calves to different levels of energy and protein in finishing diets. Pakistan journal of biological sciences: PJBS. 10(9):1398-1405.

Mustafa, A. A., Tyagi, N., Gautam, M., Chaudhari, A., \& Sediqi, J. 2017. Assessment of feeding varying levels of Metabolizable energy and protein on performance of transition Murrah buffaloes. Tropical animal health and production. 49(8):1637-1644.

Patil, L.N. 2013. Effect of feed energy level on nutrient utilisation and growth in buffalo male calves. M.V.Sc. Thesis, NDRI, Deemed University, Karnal, Haryana, India.

Pruitt, R.J., Corah, L.R. and Stevenson, J.S. 1986. Effect of energy intake after weaning on the sexual development of beef bulls. II Age of first mating, age at puberty, testosterone and scrotal circumference. J. Anim. Sci. 63:579585. 
Prusty, S., Kundu, S. S., Mondal, G., Sontakke, U., \& Sharma, V. K. 2016. Effect of energy and protein levels on nutrient utilization and their requirements in growing Murrah buffaloes. Tropical animal health and production, 48(4):807-815.

Sehgal, J.P. and Kumar, B.B. 2016. Supplementation of fermented yeast culture augments the growth and reduces the age at puberty in male Murrah buffalo calves. Buffalo Bulletin. 35(2): 179-190.

Seidel Jr, G. E., Pickett, B. W., Wilsey, C. O., \& Seidel, S. M. 1980. Effect of high level of nutrition on reproductive characteristics of Angus bulls. In 9th International Congress on Animal Reproduction and Artificial Insemination. III. Symposia (Free communication) (p. 359).

Shahzad, M. A., Tauqir, N. A., Ahmad, F., Nisa, M. U., Sarwar, M., \& Tipu, M. A. 2011. Effects of feeding different dietary protein and energy levels on the performance of 12-15-month-old buffalo calves. Tropical Animal Health and Production. 43(3):685-694.

Singh, S., Kundu, S. S., Kushwaha, B. P., \& Maity, S. B. 2009. Response of Bhadawari buffalo calves to dietary protein levels for intake, nutrients utilization, $\mathrm{N}$ balance, nutrient efficiency and growth performance. Indian Journal of Animal Sciences. 79(12):1233.

Singh, S., Kushwaha, B. P., Maity, S. B., Singh, K. K., \& Das, N. 2015. Effect of dietary protein on intake, nutrients utilization, nitrogen balance, blood metabolites, growth and puberty in growing Bhadawari buffalo (Bubalus bubalis) heifers. Tropical animal health and production. 47(1):213-220.

Tauqir, N. A., Shahzad, M. A., Nisa, M., Sarwar, M., Fayyaz, M., \& Tipu, M. A. 2011. Response of growing buffalo calves to various energy and protein concentrations. Livestock Science. 137(1-3):66-72.

Umunna, N.N., Dakintafo, A. and Carew, S.N., 1980. Influence of levels of dietary protein on performance and carcass characteristics of zebu steer fed high energy rations. Tropical Animal Production. (5):2-11.

Yazdani, A. R. 2005. Impact of protein sources on performance and biochemical changes of male growing buffalo calves. Indian Journal of Animal Research. 39(2):79-85.

\section{How to cite this article:}

Prince Chauhan, Rajneesh, Shambhvi, Narender Kumar and Shwetambri Jamwal. 2021. The Response of Different Planes of Nutrition and Analyzing its Effects on Nutrients Dynamics and Growth Rate in Ruminants: A Review. Int.J.Curr.Microbiol.App.Sci. 10(01): 843-852. doi: https://doi.org/10.20546/ijcmas.2021.1001.103 